\title{
International Urban Designs: Brands in Theory and Practice
}

\author{
Jon Lang \\ Professor Emeritus, University of New South Wales, Sydney, Australia; \\ Former chair, Urban Design Program, University of Pennsylvania.
}

\begin{abstract}
A leading author and scholar in urban design, Jon Lang discusses the increasing globalization of urban design paradigms. As international investments impose branding and the commodification of design, and professionals firms work in several different countries, he calls for a neofunctional and ecological urban design that fosters respect for the culture of places.
\end{abstract}

$U^{\prime}$ rban design has long been considered to mean the selfconscious design of cities or, much more likely, their precincts or, even more likely, a large block of a city comprised of several buildings and the open spaces among them. A number of thoughtful scholars have sought to broaden this definition to comprise the ongoing processes that shape human settlements ${ }^{1}$ but even they, when it comes to actually taking action, deal with urban design as individual project design. This paper brings attention to and questions the utility of the urban design paradigms being employed in an increasingly globalized world. These models incur significant opportunity costs when applied universally. It ultimately argues that we need a new set of generic solutions that are climatically and culturally sensitive.

\section{The Globalization of Contemporary Urban Design Practice}

We live in a growing international society as the result of the many political, economic and cultural changes taking place in the world. While today's supra-national economy seems overwhelming, international trade has had a globalizing impact on the nature of cities since the beginning of recorded history. What is happening today is, however, on a much greater scale. This observation is as true of architecture and urban design as it is for any other commercial activity. ${ }^{2}$

\section{Notes from the Editor:}

* This paper is an updated version of 'International Urban Design: Theory and Practice' published in the Proceedings of the Institution of Civil Engineers - Urban Design and Planning 162 (March 2009 Issue DPI0): $7-17$, for which the author received the Reed and Mallik Medal from the Institution. We thank the author for gratiously adapting it for FOCUS.

** FOCUS thanks Jaime Jaramillo (Cal Poly MCRP student) for helping with the image procurement for this article.

\footnotetext{
${ }^{1}$ See, for instance, Cuthbert (2006) and Carmona (2014).

2 See Olds (2001) on the internationalization of design firms and the property market, Olds and Marshall (2003) on the mega Pacific region projects, and Altani et al. (2012) on the impact of the internationalization of planning on urban Saudi Arabia.
}

Many factors contribute to the increasing globalization of urban design and architectural practice today. Real estate capital investment flows are increasingly international. Major manufacturing companies such as Sony and Daimler Benz and conventional organizations such as Bangkok Land, Henderson Land and New World Development are behind the design and implementation of major development projects in many countries. Hong Kong investors have contributed much to the development of Vancouver. Canadian money flows into the United States. Chinese property developers are building feverishly across Africa and Asia and investing in Australia. Taiwanese financial institutions are funding the building of South Saigon. They all possess a modernist attitude towards urban design while the architecture is post-modernist with a tendency to use materials that are regarded as prestigious: glass, expensive stones, and steel.

Architectural education and practice are global. A few architectural schools are trend setters and, perhaps, two dozen architectural and urban design firms dominate practice in the world today. The USA, Japan, the UK, Germany, Australia and Singapore are amongst the countries that are major exporters of design and educational services. Firms in these countries have urban design projects in China and now China is exporting architectural services to countries as diverse as Sri Lanka and Angola. China not only exports design but also construction services using its own workers.

The urban designing process tends to be one in which generic solutions that are developed within specific design paradigms are adapted to the situation at hand. Often, little heed is paid to contextual concerns. For instance, although a number of Chinese observers wonder about the quality of work that property developers, public and private, and their architects, foreign and local, are producing in places such as Lujiazui in Shanghai, Chinese development companies and their architects are reproducing the same model around the world. The East China Architectural Design Institute based in Shanghai is the designer for the Gujarat International Finance Tech City 

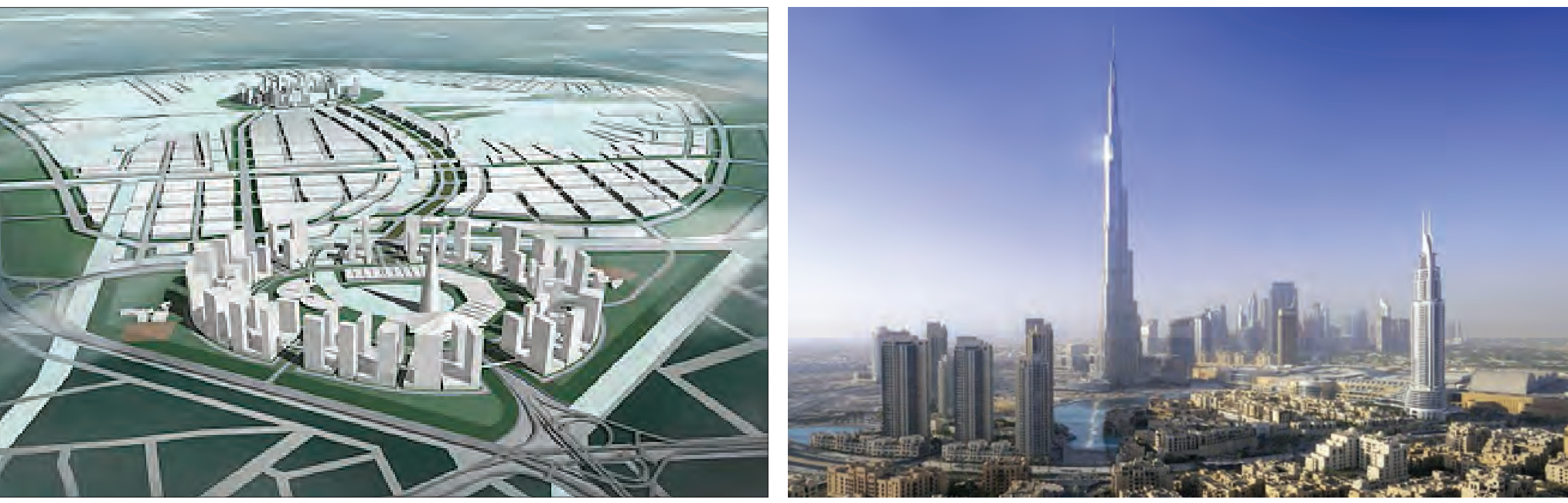

Figures 2a \& b: International rationalism at Zhandong, Zhenghou by architect Kisho Kurokawa and Associates (left). The Dubai skylight turned into a brand (right). (left: courtesy Kurokawa Associates; right: http://www.wallm.com)

quality of their city's public realm in order to: 1) provide residents and visitors with a pleasant environment in which to carry out day-to-day activities, and 2) create a positive image, or brand, in the eyes of the world and thus attract capital investments in order to compete effectively with other cities for the creative class of people. ${ }^{4}$ In doing so they have to choose between competing design paradigms that reflect competing ideas of what makes a good place (Figure 2). What then are the brands available for them to purchase?

\section{The Design Paradigms of Globalization}

Architecture and urban design play a major role in fulfilling the imagery demanded by aspiring cities. Perhaps the most prominent are the urban design of economic libertarianism and that of the neo-traditional. There are, however, other competing design ideologies - competing brands - that are seeking attention. The two streams of Modernist thought that we inherited from the beginning of the twentieth century still provide the intellectual foundations for urban designing. They are the Rationalist and the Empiricist. The former with its bold new architectural forms captures the imagination of architects

Figure 3: The generic mass housing design in China and an example in Shenzhen (2002). (photo by Kath Kolnick)

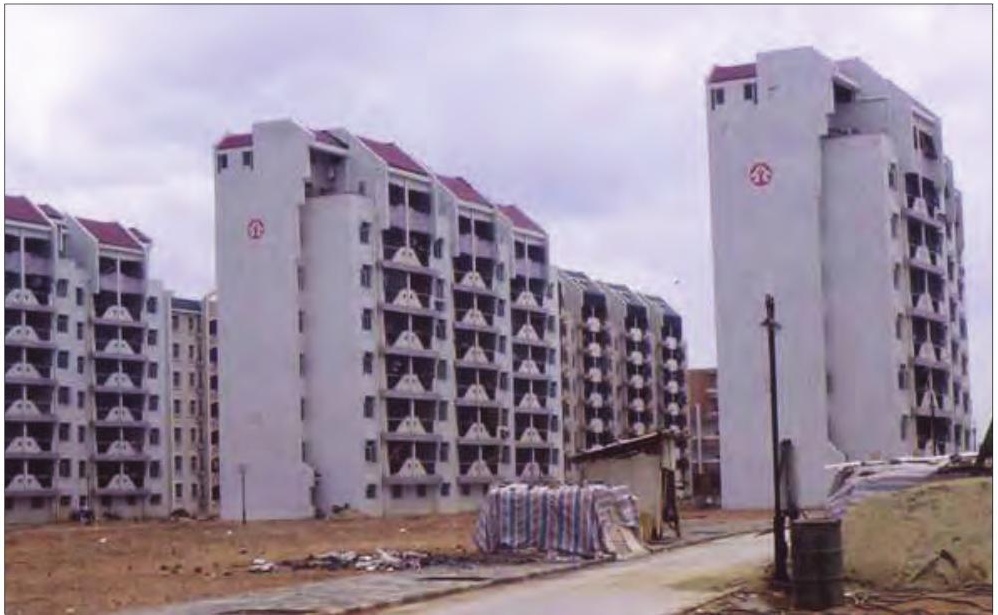

and powerful clients alike. The latter has been more concerned with reproducing what works well in new forms.

Rationalist paradigms have a clear internally valid logic based on efficiency in movement and construction and the symbolism of being up-to-date. In the 1950s and 1960s, Rationalist models developed into a 'corporate Modernism' used universally executed by many architectural firms who had adopted its basic formal characteristics as the current design paradigm. It was characterized by curtain wall buildings of glass and steel set as individual elements, 'objects in space' rather than space makers. Late in the twentieth century its qualities gave way to a more flamboyant architecture and, often, less of a pure grid-iron layout in urban design. The essence of this modernist paradigm remains the norm across the world.

For mass housing, project after project in Eastern Europe and the countries of the former Soviet Union, but also the United States and Western Europe, was imbued with the spirit of international rationalism. These schemes consist of slab and/or tower blocks set in open green space with parking for cars and children's playgrounds located in between the buildings. The model remains the standard for much of East Asia, particularly China, today. It is seen as the generic solution for housing many people in limited space, although, as it is often argued the same density can be achieved with lower buildings and a more clearly articulated public realm (Figure 3).

From the Empiricist side of twentieth century modernism the generic subdivision of a new town into districts each with its center and with districts being subdivided into neighborhoods each also with its center is still the norm for new developments. It can be regarded as the 'new town layout brand.' We have also

\footnotetext{
${ }^{4}$ Although much disputed the perception is that if cities are to prosper they require a population of people who are innovators in both the arts and technology (Florida, 2002).
} 
inherited the garden city concept and the townscape approach to urban design from the Empiricitsts. The former is still with us; the latter, with a little imagination, can be said to have evolved into a number of Neo-traditional approaches to urban design.

The generic garden city model is still widely applied to new suburban design around the world. In many cases the principles behind the creation of the model are neglected; only the imagery is retained. Although developed for cool temperate climates, the model has been used as the basis for new town design in a variety of climatic and cultural contexts, including arid zones where designs would be better off 'browned' rather than 'greened'. The greenery and the consumption of space are, however, seen as prestigious and so meet the aspirational needs of many of the middle-class particularly in countries where signficant economic growth is recent. The Shongsang Lake development (2004 and beyond), for instance, is based on car-ownership rather than the needs of pedestrians (Figure 4).

The urban design projects being developed around the world are clearly based on a handful of global brands. Many have been criticized on a number of grounds but the paradigms continue to be followed. They seem to work well-enough; they are, in economic terms, satisficing solutions.

\section{Does It Matter?}

Globalization has been seen as the solution to many of the world's ills and the way to eliminate poverty from the world. In the late nineteenth century Henry George (1839-1897) believed that the universalization of the world's economy by free-trading among nations was highly desirable. His ideas have been influential on libertarian thinking to this day and spill over into urban design. In architecture and urban design globalization has been seen as the natural answer to common problems being faced everywhere. It assumes the universality of a world culture.

Walter Burley Griffin (1876-1937), is amongst those architects who assumed that there is 'no longer any difference between races, and there should be no artificial barrier erected between them' (Griffin, 1946). In his design for Canberra he merged two designs paradigms - the City Beautiful and the Garden City - that were developed in Europe and America during the late nineteenth and early twentieth centuries. The most celebrated statement on the universalism of the problems facing architects was that by Le Corbusier (1923): 'I propose a single building for all nations and all climates.'

The globalization of urban design might seem to be inevitable in an age of patronage and the power of international corporations. Perhaps the observation of Werner Hegemann (1881-1936) on the imagery of Le Corbusier's urban design proposals sums the situation up. They, he thought, would be sought after:

“. . . not because they are desirable, healthy, reasonable ... but because they are theatrical ... unreasonable and generally harmful and ... part of the money making activity of the metropolis." (Hegemann cited in Oeschlin 1993, 287)

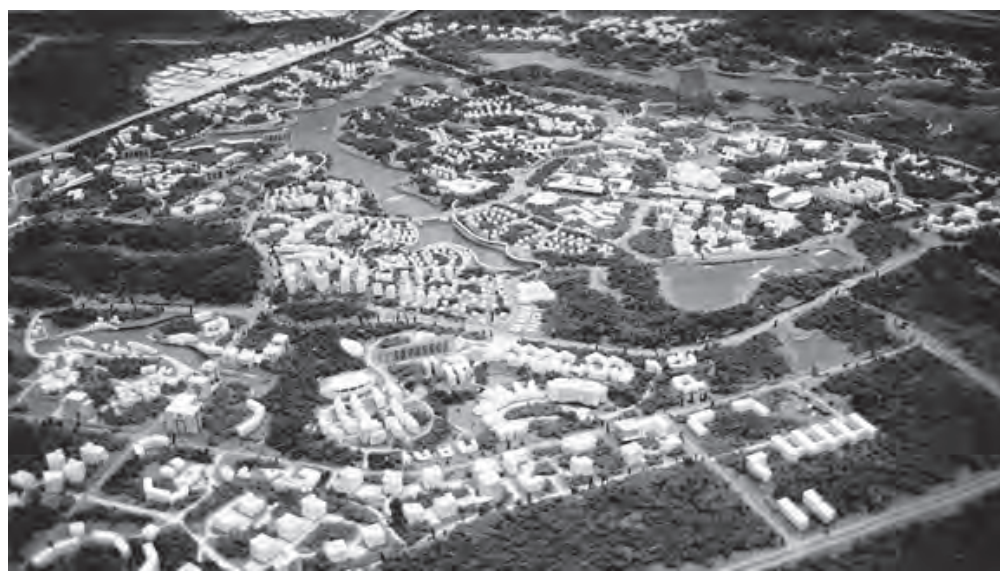

Figure 4: The model of Shongshang Lake, Guangdong, China (2004). (photo by the author)

Yet Hegemann too sought a universal urbanism that would benefit humanity (Collins, 2005).

In the face of universalizing forces much remains local. In China the universal housing types end up with common touches. Laundry is still hung out on balconies to dry and the people themselves and their activities locate the developments in the country. The built environment is only a backdrop to life. Serious questions can, nevertheless, be raised about the urban designs of the globalized economy. The need to create a more sustainable world as many non-renewable resources get depleted, the needs of the poor, the quality of a locale's natural ecology, and issues of a sense of place remain largely unaddressed and when addressed get treated superficially. If this situation prevails what are the remedies; what are the alternative paradigms? What other brands are available for purchase?

\section{Urban Designing for a Sense of Locale: Current Paradigms}

In the urban design field, both in theory and practice there has been a strong reaction to the universalizing tendencies of the urban designs of globalization. While seen as a recent phenomenon this reaction goes back, at least, to colonial architects of the British and French attempting to localize their work by incorporating elements of the aesthetic traditions of specific colonies. In the nineteenth century there were the Indo-Saracenic buildings in India and in the twentieth century the work of French architects in North Africa and Vietnam. ${ }^{5}$

Current efforts to create a paradigm for localizing new urban designs vary from those designers resurrecting vernacular processes to those proposing neo-traditional designs and to those advocating a critical regionalism. Of these the Neotraditional in the guise of the New Urbanism has attracted the most attention. Before it, postmodernists captured the imagination of a minority of architects and clients by rejecting

\footnotetext{
${ }^{5}$ See Lang, Desai and Desai (1997: 99-106) for an overview of the IndoSaracenic architecture of British Colonial architects.
} 
the blandness of modernist urban designs. They sought to inject a greater liveliness and a sense of locality into their designs. They, however, attempted to meet this end by incorporating traditional elements in an abstract rather than a literal form. The associations were not recognizable to lay people (Groat and Canter, 1979). The abstractions had to be explained. A strong reaction to both modernism and post-modernism can also be traced back to the mid-twentieth century when a number of architects were attracted by vernacular architectures that had evolved over time to meet the climatic characteristics and cultural traditions of specific locales.

The book by Bernard Rudofsky (1905-1988) and the exhibition at the Museum of Modern Art in New York on Architecture without Architects made the intelligentsia look again at settlement patterns and buildings created with limited resources (Rudofsky, 1964). In creating neo-vernacular designs architects failed, however, to consider the aspirations of the inhabitants of those locales. The best known example of such an experience is that of the design of New Gournia near Luxor in Egypt. Hassan Fathy (1900-1989) largely replicated the design of Gournia, a village due to be flooded by the Aswan Dam on the Nile. Fathy certainly demonstrated the utility of indigenous materials such as mud-brick for the modern world but his design, both in its symbolic and utilitarian qualities, represented a world the villagers were trying to escape. The new village was never fully inhabited. The neo-vernacular continues to attract the attention of designers both in holistic form or in bits and pieces (Figure 5).

The Neo-traditionalists have been more successful by relying on the principles rather than simply the forms of traditional architectures in their new designs. They have, however, also fallen into the trap of copying past forms and of assuming past ways of life would endure. The design products are valid only to the extent that their assumptions are accurate. The question is: On what traditions does one draw?

Figure 5: The Neo-Vernacular Shri Ramiaiah Institute campus, Bengaluru,1990s. (photo by the author)

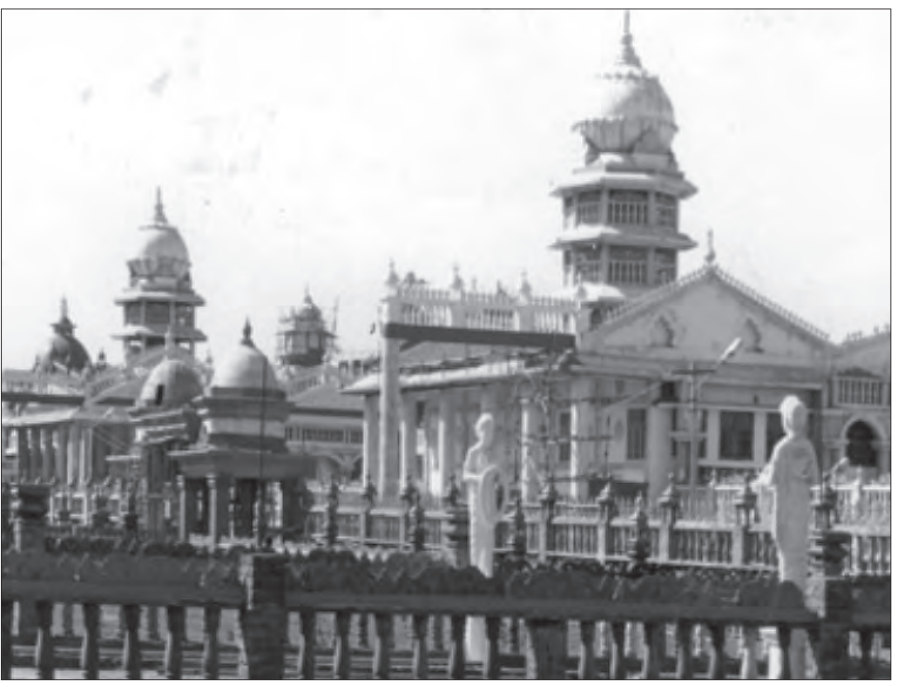

\section{Neo-traditional Urban Design}

The university town of Louvain-la-Neuve (1970s+) was designed to stand in strong contrast to the somewhat soul-less modernist universities built in Belgium during the 1960s (Figure 6). The architecture is Neo-modernist, that is, it is clearly of its time but richer in detail and general character than modernist forms but its urban design harkened back to the past. In this case the medieval city and the embedding of a university in a town rather than being isolated from it in a separate campus was the model.

There are many other examples of neo-traditional urban designs. Seaside, Florida (1979+) with its houses based on the regional patterns was an early example of the work of Andrés Duany and Elizabeth Platter-Zyberk. It has a clear brand image and been a precedent for much that has followed. It placed the requirements of pedestrians to the forefront and through strong design guidelines created a uniformity in appearance that relates Seaside to the architecture of north-west Florida.

Poundbury in England (1993+) and the Income Tax Colony (1997) in India are other examples created by prominent architects (Figure 7). Their quality ultimately depends on the appropriateness of the precedent on which they are based. Jaisalmer in the Thar Desert is a very different world to the monsoon climate of Navi Mumbai. The precedents for the buildings in Poundbury are a very mixed and hardly local set. Much Neo-traditional design, nevertheless, works well multidimensionally today because we exaggerate the changes in the ways of life of the middle-class since the world was turned upside down, technologically, socially, and politically during the first half of the twentieth century.

In an urban context the core of Battery Park City (1979-2010), the World Finance Center, is international in character and a precent for the core of the Docklands in London and the Abandoibarra precinct of Bilbao in Spain. They were, after

Figure 6. The new university town of Louvain-la-Neuve, Belgium, central axis, Michel Woitrin and Raymond Lemaire, urban designers, 1970. (photo by Katsura; http://europhilomem.hypotheses.org/702

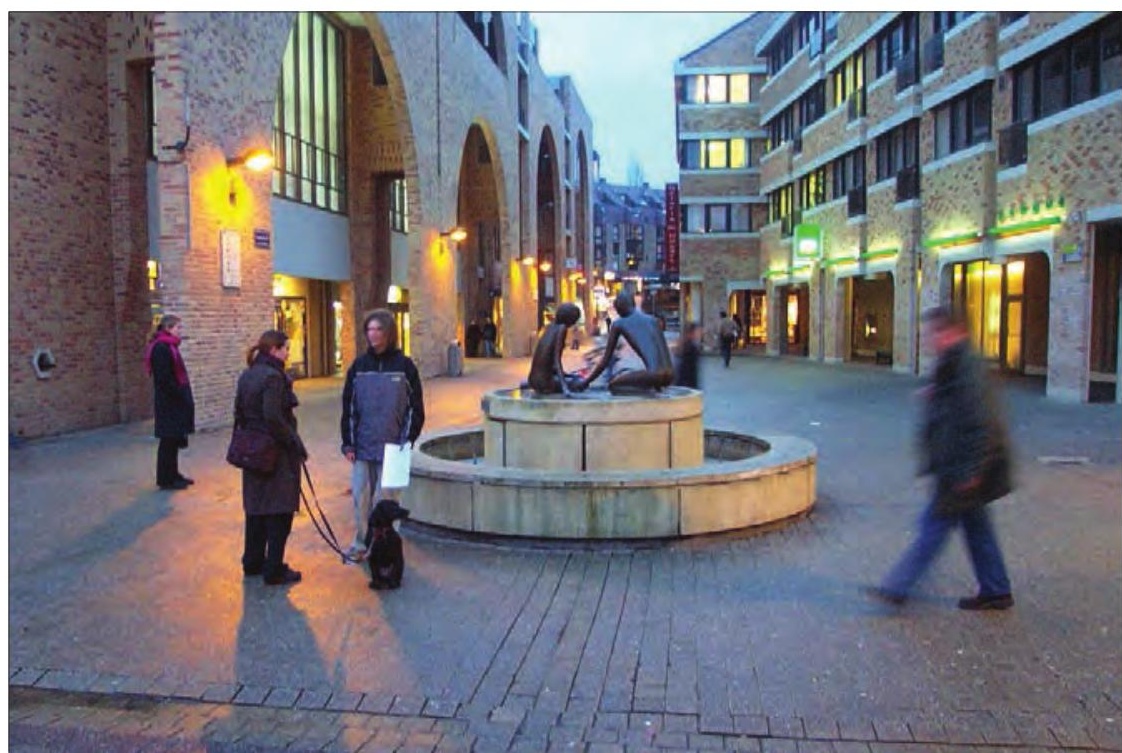



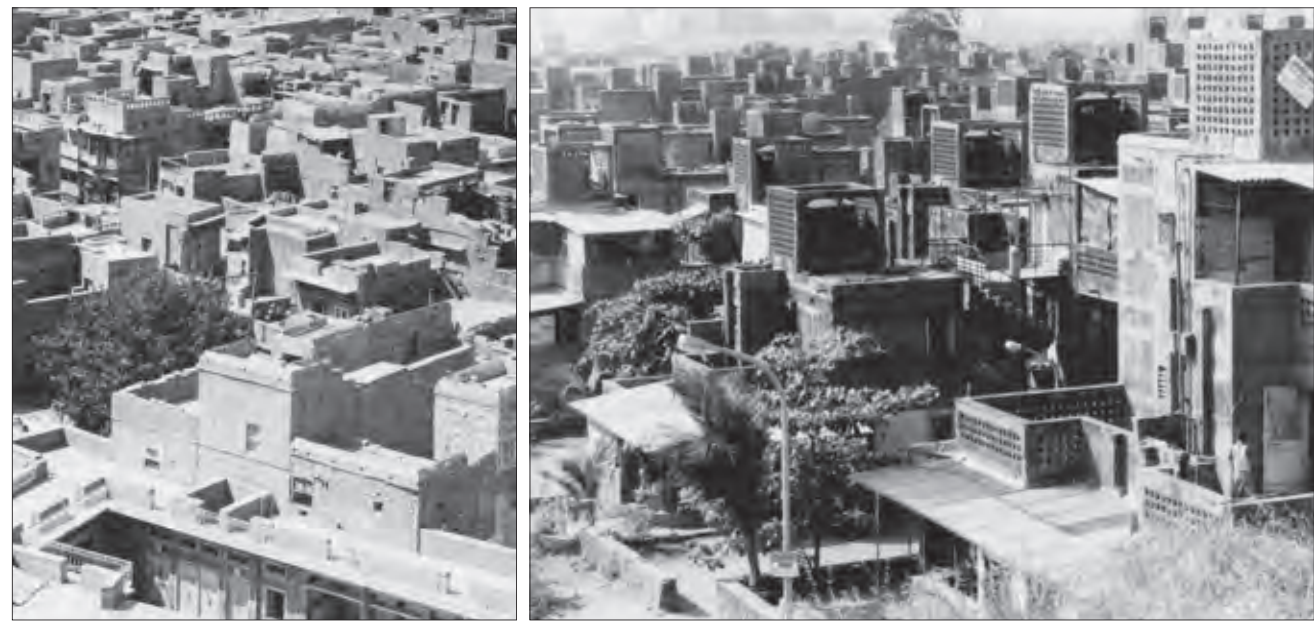

Figure 7: The Income Tax Colony, Navi Mumbai: the precedent Jaisalmer, Rajasthan (left) and the design (right), Raj Rawal, architect, 1996+. (photos by the author) all, designed by the same architect: César Pelli. The block design and the appearance of the residential buildings was, in contrast, based on the neighborhoods of New York that New Yorkers like -Gramercy Park and Morningside Heights in particular. The same design attitude prevailed in the design of Paternoster Square in London (2003). Critics are dismissive of its architecture and the square being only quasi-public property, but the square functions well on many dimensions; it has the qualities that result in lively urban spaces (Figure 8).

Much Neo-traditionalist urban design is seen by locals as being part of their heritage. It is often disparaged as being out of date and not creative. The cognoscenti of the art academy take a more radical view of how the future, present and the past should go together in urban design and architecture. Critical regionalism is one such approach.

\section{Critical Regionalism}

A number of architects reject the banality of modernist urban designs, the individualist abstract expressions of postmodernist designs and the universalism of the urban designs of commercial globalization. They seek to be both modern and local in their designs. While critical regionalism is, like neotraditional architecture, seen to be a brand of design developed in the late twentieth century its roots go much further back.

Florestano Di Fausto is an example of a pre-World War Two architect seeking to be both modernist and local. ${ }^{6}$ In his designs in Italian controlled Libya, Di Fausto incorporated indigenous patterns that responded to climatic, cultural necessities, and local motifs in an otherwise Italian Rationalist architecture and urban design. He, like our contemporary critical regionalists, believed that design should be grounded in its context and be related to historical traditions without losing a sense of modernity.

Di Fausto's works in Libya had a simplicity of form but were

\footnotetext{
${ }^{6}$ See Anderson (2010) for an overview of the work Di Fausto and McLaren (2006: 183-218) on Di Fausto's regionalism.
}

broadly functional in a manner sought by more renowned architects such as Alvar Aalto and Jørn Utzon. Alvaro Siza is a current architect who applies the concept of critical regionalism to urban design as in Quinta da Malagueria in Portugal (Figure 9). While of much interest to the cognoscenti and apparently meeting the needs of local people, it is not the type of urban environment that has attracted the widespread attention of contemporary politicians.

\section{Designs through the Sustainable cities Paradigm}

Recent efforts to develop generic models of sustainable urban environments include explorations for the generic form of cities given their climate and basic cultural ethos and the somewhat fragmented ideas of the Landscape Urbanists. These explorations are exemplified by the similar designs for cities in the United Arab Emirates by the Office for Metropolitan architecture (OMA) under the leadership of Rem Koolhaas and the Foster Partnership (Figure 10). The former's design for Masadar City and the latter's design for Ras El Khaimah have many of the same urban design characteristics. That is not surprising as they are responding to essentially the same environmental conditions.

Figure 8: Neo-traditionalism at Paternoster

Square, London. (photo by Vicente del Rio)

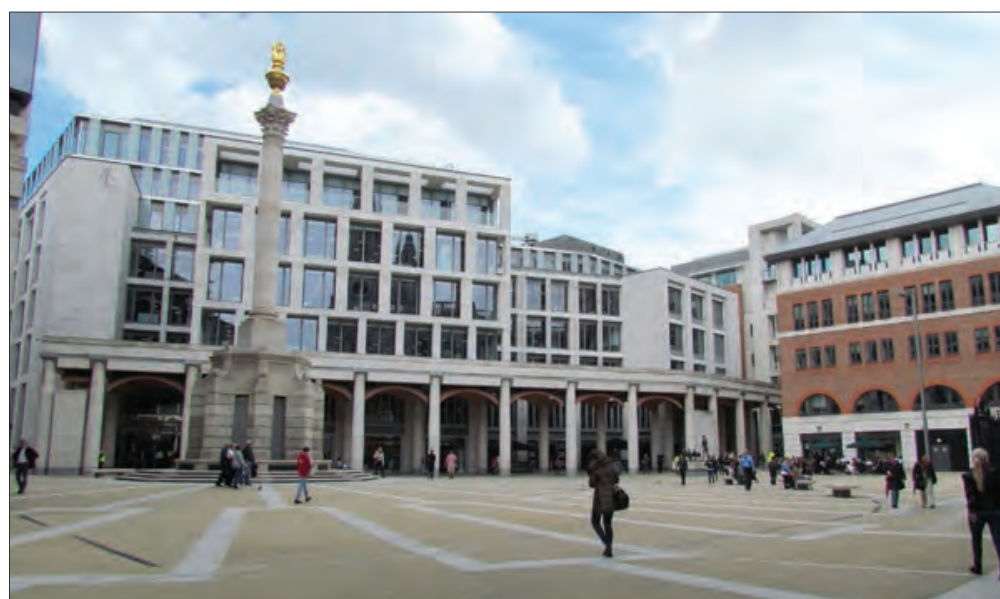


case studies, and deducing patterns from research-based theoretical knowledge, but we rely more heavily on personal experiences and beliefs. These experiences are important and cannot be discounted but are inevitably heavily biased by our own cultural and social frameworks.

It is clear that the rational model cannot be implemented in a step-by-step fashion. To do so would require comprehensive knowledge and objective thinking. Designing programs and the consequent built environments is a more fragmented process that involves many iterations of thought. The model does, however, provide an 'ideal' framework for asking serious questions about how to design a salubrious city or precinct that is full of opportunities for people to lead a rich life without deleterious effects on the natural flora and fauna of a place. The argument against attempting to follow such a process is that it is time consuming. In the 'real' world decisions have to be made quickly so we have to rely on the brands of good urban form that we have at our disposal.

Modernist urban design, despite many premature obituaries, is alive and well in many places. Such designs function well when the assumptions about people, nature and ways of life on which they are based coincide with contemporary culturebased activity systems, economic conditions and aesthetic values. People do adapt to them well-enough even if the designs do not function well. The modernist urban design paradigm continues to be employed by city planners and architects engaged in new town and housing precinct design in countries such as Korea and China. It is valued for its up-todate qualities and the privacy it affords. It, has, however been largely rejected in countries such as the United States and the United Kingdom, the so-called Anglo-Saxon world, and in Continental Europe. Even where it is still in vogue, there is a great sense of opportunity costs - the designs could have been better if another paradigm had been followed and/or a much more thorough programming process with community input had been followed. In many east European countries such as Hungary, the unused and meaningless open spaces between blocks of buildings are being filled in to create an environment that affords a richer range of settings for engagements in a communal life. It is no easy design task.

For commercial areas, the urban designs of international economic libertarianism rules supreme in many places and particularly in the modernizing world. Its bold individual buildings set in space attract the attention of many corporate and political leaders around the world today. It assumes the individual motor vehicle is the major mode of transportation and the pedestrian is of little consequence. It is the image that counts. In one proposed design for the proposed new CBD for Dammam in Saudi Arabia the buildings are set in a lush green precinct replete with ponds (Figure 10). Such a design stands in strong contrast to a neo-traditional design for the same site.

The density of the two schemes responds to the same program, or brief, but the way of handling the density is very different.

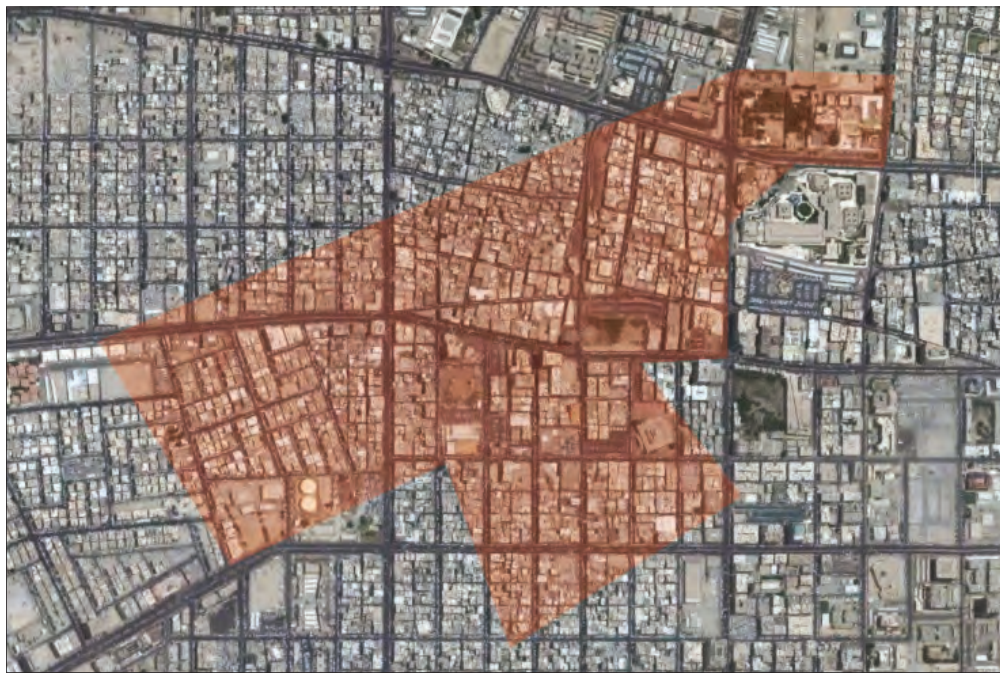

Figure $10 a, b$ \& c: Two proposals for the new CBD in Central Dammam, Saudi Arabia (top). The economic libertarian (middle) and the neotraditional (bottom), 2007. (souces: a) Google Earth + author archives; b) author; c) courtesy Marina Khoury, DPZ Architects)
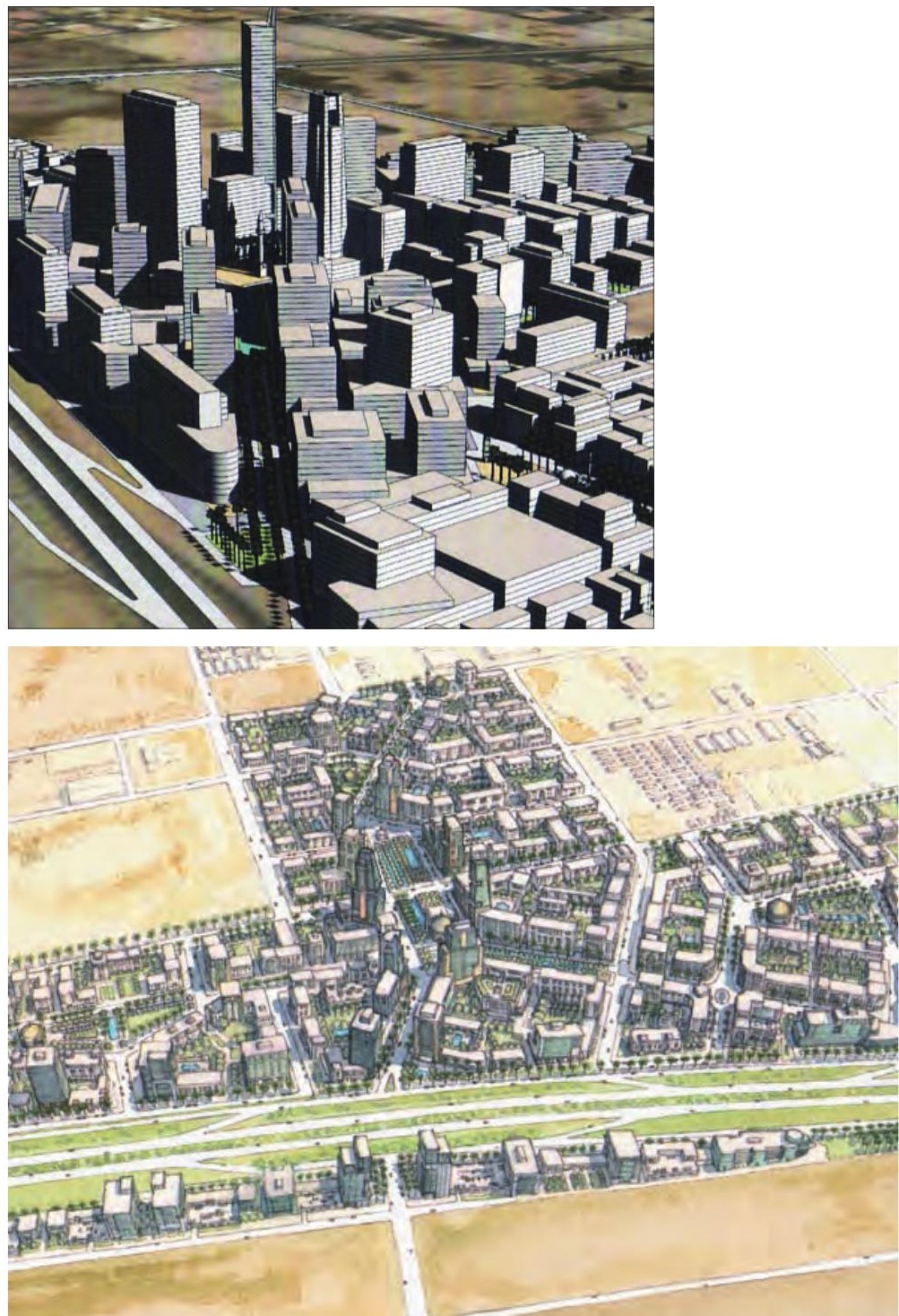
The neo-traditional design follows the generic qualities of Dammam's existing street pattern, mixed-use qualities, patterns of climate control, and housing patterns. It provides a much richer set of offerings for the pedestrians in a shaded world. Which is the better scheme? It depends on the criteria used in the evaluation.When I show these two schemes to lay people, architects and students at public and professional society presentations, the economic libertarian scheme is clearly the preferred proposal in the audience's eyes; it is seen as up-to-date. Ultimately it is the power elite that make decisions but they can be persuaded by strong arguments.

How does one move ahead? I have been an advocate for a knowledge-based neo-functional ecological urban design process but have been told that 'designers simply do not and will not work that way. If this is indeed the case what is needed by urban designers is a new and broad set of generic solutions that deal with diverse cultural environments and climates and assume different levels of technological and economic constraints. This range of possibilities would present professionals working under severe time constraints with a set of models that would form the basis for asking serious questions about how best to address the situation at hand. Whose job is it to produce them? Surely it is that of the academic community.

\section{References}

Altani, B; M. Sibley and L. Munuchin. (2012). Evaluating the impact of the internationalization on urban planning in Saudi Arabia. In The Sustainable City VII, Vol 1, edited by M. Pacetti, G. Passerini, C. A. Brebbia and G. Latini. Southampton: WIT Press.

Anderson, Sean. (2010). The light and the line: Florestano Di Fausto and the Politics of Mediterraneità. Californina Italian Studies 1(1).

California Italian Studies 1(1). Retrieved from http://escholarship.org/uc/item/9hm1 p6m5\#page-1; 19 ${ }^{\text {th }}$ March 2014.

Carmona, Matthew. (2014). The place-shaping continuum: a theory of urban design process. In Journal of Urban Design 19 (1): 2-36.

Collins, Christiane Crasemann. (2005). Werner Hegemann and the Search for a Universal Urbanism. New York: W. W. Norton.

Cuthbert, Alexander. (2006). The Form of Cities. Oxford: Blackwell.

Florida, Richard. (2002). The Rise of the Creative Class and how it is transforming work, leisure, community and everyday life. New York: Basic Books.

Griffin, Marion M. (1946). The Magic of America. Unpublished manuscript. New York: New York Historical Society.
Groat, Linda and David Canter. (1979). A study of meaning: Does Post-Modernism communicate? In Progressive Architecture 60 (12): 84-87.

Kuitert, Wybe (2013): Urban landscape systems understood by geo-history map overlay. In Journal of Landscape Architecture 8 (1), p. 54-63.

Lang, Jon. (2005). Urban Design: A Typology of Procedures and Products illustrated with over 50 Case Studies. Oxford: Architectural Press.

Lang Jon and Walter Moleski. (2010). Functionalism Revisited: Architectural Theory and Practice and the Behavioral Sciences. Farnham: Ashgate.

Le Corbusier. (1923). Vers une Architecture. Paris: Arthaud. Translated by Fredrick Etchells as Towards a New Architecture. New York: Praeger, 1970.

Marshall, Richard. (2003). Emerging Urbanity: Global Projects in the Asia Pacific Rim. London: Spon.

McHarg, lan. (1969). Design with Nature. Garden City. NY: Natural History Press.

Miao, Pu. (2003). Deserted streets in a jammed town. The gated community in Chinese cities and its solution. Journal of Urban Design 8 (1), p. 45-66.

Mills, C. Wright. (1956). The Power Elite. New York: Oxford University Press.

Oeschlin, Werner. (1993). Between Germany and America: Werner Hegemann's approach to urban planning. In Berlin/New York Like and Unlike, Essays on Architecture and Art from 1870 to the Present, edited by Josef Paul Kleihues and Christina Rathberger. New York: Rizzoli.

Olds, Kris. (2001). Globalization and Urban Change: Capita, Culture and the Pacific Rim Mega Projects. Oxford: Oxford University Press.

Rowe, Colin. (1963). Program versus paradigm. In Cornell Journal of Architecture 2, p. 2-19.

Rudofsky, Bernard. (1964). Architecture without Architects: an Introduction to non-pedigreed Architecture. Garden City, NY: Doubleday for the Museum of Modern Art.

Steiner, Frerick R. (2011). Landscape Ecological Urbanism: Origins and Trajectories. In Landscape and Urban Planning 100, p. 333-337. 